\title{
Evaluasi Implementasi Pembelajaran Daring selama
Pandemi Covid-19
}

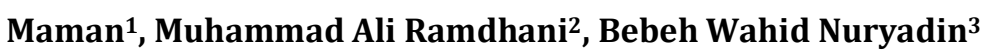

1,2,3Universitas Islam Negeri Sunan Gunung Djati Bandung, Indonesia

E-mail:maman@unpas.ac.id,muhamadaliramdhani@uinsgd.co.id, bebehwahid102@uinsgd.ac.id

\begin{abstract}
Article Info
Article History

Received: 2021-11-15

Revised: 2021-11-28

Published: 2021-12-17

Abstract

This research is a study on evaluating the implementation of online learning during the COVID-19 pandemic in terms of the implementation of online learning and the impact of online learning policies. This type of research is qualitative with library research method. The results of the study show that online learning in elementary schools during the COVID-19 pandemic is able to increase knowledge, skills, mastery of

Keywords:

Evaluation;

Learning;

Online;

Pandemic;

Covid-19. technology, autonomy, creativity, independence of students and shows the readiness of school institutions, both teachers and facilities to carry out distance learning. The results of data analysis show that online learning is less than optimal in improving students' abilities, especially non-academic ones such as character building, interaction effectiveness in learning, complete learning, personality enhancement, giving motivation that is oriented to exemplary life and evaluation accuracy of improving
\end{abstract} students' abilities.

\begin{tabular}{l}
\hline Artikel Info \\
\hline Sejarah Artikel \\
Diterima: 2021-11-15 \\
Direvisi: 2021-11-28 \\
Dipublikasi: $2021-12-17$
\end{tabular}

Kata kunci:

Evaluasi;

Pembelajaran;

Daring;

Pandemi;

Covid-19.

\begin{abstract}
Abstrak
Penelitian ini merupakan kajian tentang evaluasi implementasi pembelajaran daring selama pandemi covid-19 ditinjau dari implementasi pelaksanaan pembelajaran daring dan dampak dari kebijakan pembelajaran daring. Jenis penelitian ini adalah kualitatif dengan metode library research. Hasil dari penelitian menunjukkan bahwa pembelajaran daring di Sekolah Dasar selama pandemik COVID-19 mampu meningkatkan pengetahuan, keterampilan, penguasaan teknologi, otonomi, kreativitas, kemandirian peserta didik dan menunjukkan kesiapan institusi sekolah baik guru maupun fasilitas untuk melaksanakan pembelajaran jarak jauh. Hasil analisis data menunjukkan bahwa pembelajaran daring kurang maksimal pada peningkatan kemampuan peserta didik khususnya yang bersifat non akademis seperti pembentuk karakter, efektivitas interaksi dalam pembelajaran, pembelajaran tuntas, peningkatan kepribadian, pemberian motivasi yang berorientasi pada keteladanan hidup dan akurasi evaluasi terhadap peningkatan kemampuan peserta didik.
\end{abstract}

\section{PENDAHULUAN}

Pada awal tahun 2020 dunia digemparkan dengan kejadian infeksi berat yang berasal dari Wuhan, Provinsi Hubei, China, 11 februari 2020, WHO menamakanya sebagai COVID-19. Covid-19 merupakan penyakit yang disebabkan oleh syndrom pernapasan akut yang dapat menular, coronavirus 2 (servere actual respiratory syndrome corona virus 2 atau SARS-CoV-2). menurut (Handayani, 2020) bahwa virus corona merupakan zoonosis yang berasal dari hewan dan ditularkan ke manusia, manusia ke manusia yang di prediksi melalui droplet dan kontak dengan virus yang dikeluarkan dalam droplet. Virus COVID-19 menyebar dengan cepat hampir ke seluruh penjuru negara di dunia seperti Indonesia, Korea Selatan, Italia, Amerika Serikat, India, Singapura, Australia dan lainlain. Wabah ini telah menyebabkan ratusan ribu nyawa warga dunia melayang, dan kelumpuhan di bidang lain seperti ekonomi, sosial, dan pendidikan sangat

\section{dirasakan.}

UNESCO dalam (Nasser, 2021) mengungkapkan bahwa 61 negara telah mengumumkan atau menerapkan penutupan lembaga pendidikan dalam upaya untuk memperlambat penyebaran penyakit. Menurut UNESCO juga, lebih dari 39 negara telah menutup sekolah, perguruan tinggi dan universitas, yang telah berdampak pada lebih dari 420 juta anak-anak dan kaum muda. Di bidang ekonomi tak kalah dasyat dampak COVID-19. Karena penularan virus corona ini sangat cepat, maka Organisasi Kesehatan Dunia atau WHO pada tanggal 11 Maret 2020 menetapkan bahwa corona sebagai darurat global pandemi. Data yang didapat dari Badan Nasional Penanggulangan Bencana (BNPM) sebagaimana dikutip (Mayasari, 2021) mengemukakan bahwa pada tanggal 4 Mei 2020, angka positif Covid-19 secara Global berjumlah 3.595.667 orang, 1.166 .556 orang dinyatakan sembuh, dan 249.225 orang dinyatakan 
meninggal. Di Indonesia tertinggi setelah Cina tanggal 5 April 2020 terkonfirmasi Covid-19 berjumlah 2.273 orang, sembuh 164 orang, dan meninggal 198 orang, maka dari itu kebijakan yang diambil pemerintah Indonesia adalah dengan menerapkan lockdown, dan PSBB di sejumlah daerah serta memberlakukan social distancing dalam upaya memutuskan rantai penyebaran Covid-19. Beberapa langkah dilakukan dengan cepat oleh pemerintah agar virus corona tidak menular dengan cepat yaitu menerapkan work from home (WFH), Social Distancing, dan lain-lain. Masyarakat juga diedukasi untuk menerapkan pola hidup sehat dengan cara mencuci tangan dengan sabun sesering mungkin, memakai masker ketika berpergian, dan juga menjaga jarak.

Dampak COVID-19 terhadap pendidikan sangat terasa. Sejak akhir bulan Maret-Juni seluruh layanan pendidikan lumpuh total. Pembelajaran terhadap peserta didik dilakukan secara daring. Guru memberikan pembelajaran melalui beragam aplikasi daring seperti google form, youtube, email, google meet, zoom, dan lain-lain. Anak-anak belajar di rumah. Menurut Anna Sun and Xiufang dalam (Irwansyah, 2021) bahwa penggunaan berbagai aplikasi online telah memberikan peluang bagi pengembangan komunitas dan grup online seperti Email, drive Google, Google doc, Google hangout, dropbox, facebook, Twitter, dan lain-lain. Telah banyak digunakan di ruang kelas online.

Untuk menjaga keberlangsungan proses pembelajaran tetap berlangsung, pemerintah Indonesia pada tanggal 24 Maret 2020 mengeluarkan kebijakan strategis pengelolaan pendidikan selama pandemic COVID-19. Menteri Pendidikan dan Kebudayaan Republik Indonesia mengeluarkan Surat Edaran Nomor 4 Tahun 2020 Tentang Pelaksanaan Kebijakan Pendidikan Dalam Masa Darurat Penyebaran COVID-19. Dalam Surat Edaran tersebut keberlangsungan proses pembelajaran disinggung pada point kedua. Proses pembelajaran dilakukan di rumah melalui pembelajaran daring/jarak jauh dengan memberikan pengalaman belajar yang bermakna, meningkatkan kecakapan hidup, pembelajaran bervariasi, umpan balik. Pembelajaran jarak jauh dilakukan dengan memanfaatkan aplikasi daring. Guru, siswa dan warga sekolah dituntut untuk memanfaatkan aplikasi teknologi informasi yang tersedia agar pembelajaran jarak jauh tetap berjalan. Interaksi pembelajaran online dilakukan dengan mengirimkan tugas via aplikasi e-learning, memberikan tugas, diskusi online, dan meninjau proses pembelajaran (Allo, 2020).

Menurut Keengwe, J., \& Georgina dalam (Arifudin, 2020) bahwa perkembangan teknologi memberikan dampak positif bagi pelaksanaan pembelajaran. Konsep dari pembelajaran jarak jauh yang lebih dikenal dengan istilah distance learning atau distance education, yaitu suatu sistem pendidikan dimana terdapat pemisahan antara pengajar dan siswa baik secara ruang dan/atau waktu. "Distance learning" dikembangkan pertama kali di Amerika Serikat, Perancis, Jerman, dan Inggris pada pertengahan tahun 1800. Pada tahun 1840, Sir Isac Pitman mengajar jarak jauh menggunakan surat. Dan pada tahun 1980 an, International Correspondence Schools (ICS) membangun metode perkuliahan "homestudy courses" yang pada saat itu dikarenakan faktor kemananan pada era itu. Gambar di bawah ini (Yaniawati, 2013) adalah proses sejarah munculnya teknologi pembelajaran jarak jauh berbasis web.

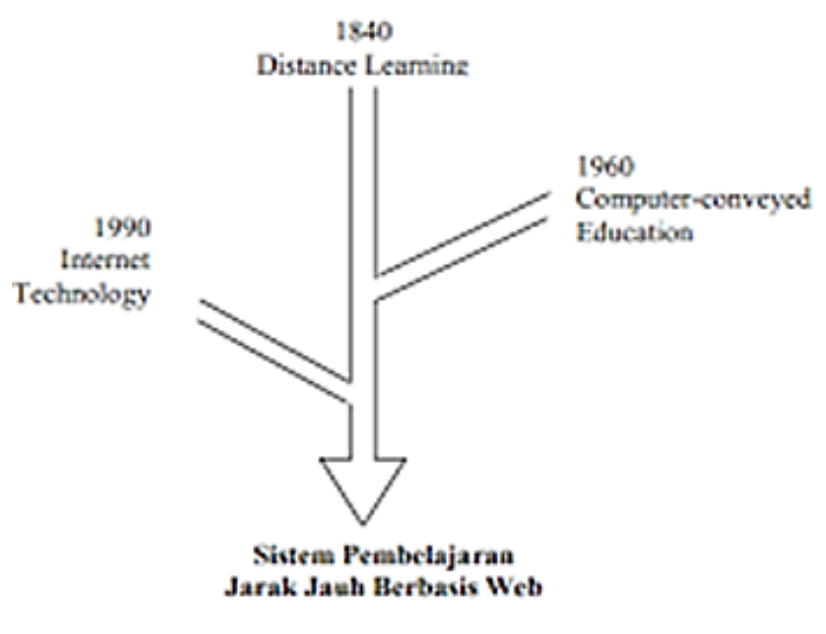

\section{Gambar 1. Sejarah Distance Learning}

Banyak sekali sistem pembelajaran jarak jauh yang telah diterapkan, yang pada dasarnya dapat dibagi dalam dua kategori: sistem berbasis video dan sistem berbasis data. Sistem berbasis video mulai muncul tahun 1960-an dimana ketika itu merupakan era meluasnya kepemilikan televisi. Dengan merekam materi belajar ke dalam kaset video dan diputer pada stasiun-stasiun televisi, sistem ini memiliki jangkauan geografis yang cukup besar. Salah satu kelemahan sistem ini adalah kurangnya interaksi dan komunikasi dua arah antara pengajar dan peserta. Untuk sistem berbasis data dapat kita klasifikasikan dalam dua kategori: groupware dan internet. Pada groupware, biasanya menggunakan perangkat lunak yang termasuk dalam kategori computersupported coorperative ( $\mathrm{cscw}$ ), dimana melalui perangkat lunak ini, sudah tersedia layanan 
seperti electronic messaging, 1840 Distance Learning $1960 \quad$ Computer-conveyed 1990 Education Internet Technology Sistem Pembelajaran Jarak Jauh Berbasis Web 8 data conferencing, dan messaging gateways.

Pembelajaran jarak jauh atau pembelajaran daring adalah pembelajaran yang melibatkan internet. Pembelajaran daring ini berkaitan dengan apa pun yang disampaikan, diaktifkan, atau dimediasi oleh teknologi elektronik untuk tujuan pembelajaran secara eksplisit (Wicaksono, 2017). Sementara menurut (Maltz, 2005), istilah e-learning diterapkan dalam berbagai perspektif termasuk pembelajaran jarak jauh online, dan pembelajaran hibrid. Sedangkan E-learning, menurut (Arina, 2018) didefinisikan sebagai penggunaan teknologi informasi dan komunikasi dalam beragam proses pendidikan untuk mendukung dan meningkatkan pembelajaran di institusi pendidikan tinggi, dan mencakup penggunaan teknologi informasi dan komunikasi sebagai pelengkap tradisional ruang kelas. Adapun menurut Elchanan dalam (Tanjung, 2019) bahwa istilah e-learning mengacu pada pencapaian dan penggunaan pengetahuan yang sebagian besar difasilitasi dan didistribusikan dengan cara teknologi informasi. Menurut (Wentling, 2000) bahwa Pembelajaran daring memiliki sisi positif dan negatif.

Pembelajaran daring sangat memudahkan peserta didik dan guru untuk melakukan interaksi pembelajaran kendati hanya melalui dunia virtual. Menurut (Karim, 2004) mengutip beberapa tokoh mengungkapkan manfaat pembelajaran daring antara lain: keefektifannya dalam mendidik siswa, penggunaannya sebagai pengembangan profesional, efektivitas biaya, kesetaraan kredit, dan koneksi yang mudah. Mengutip peneliti sebelumnya, (Wentling, 2000) mengungkapkan manfaat pembelajaran daring yakni mendorong fleksibilitas waktu dan tempat belajar, memudahkan akses informasi, mendorong partisipasi siswa, mempertimbangkan perbedaan kemampuan individu, membantu kompensasi kelangkaan staf akademik, meningkatkan kecepatan informasi.

Sementara Moore dan Kearsley dalam (Nadeak, 2020) mengungkapkan manfaat pembelajaran daring yakni meningkatkan akses untuk belajar dan pelatihan, memperbarui keterampilan, meningkatkan efektivitas biaya sumber daya pendidikan, meningkatkan kualitas struktur pendidikan, meningkatkan kapasitas sistem pendidikan, mendorong kesetaraan, promosi pendidikan, memperluas kapasitas, menawarkan kombinasi pendidikan, menambah dimensi internasional. Sementara menurut Keller dan Cernerud dalam (Hasbi, 2021) keunggulan pembelajaran daring adalah memudahkan aksesibilitas, mendorong kreativitas, mengembangkan kemampuan kognitif, efektivitas biaya, mempromosikan penelitian peserta didik, meningkatkan Keterampilan komputer dasar, memunculkan kesetaraan, mempersempit hambatan geografis dalam hal pendidikan. Beberapa manfaatkan yang diungkapkan oleh para peneliti sebelumnya menunjukkan keunggulan pembelajaran daring yang memudahkan institusi pendidikan baik sekolah, guru dan peserta didik tetap menjaga keberlangsungan proses pembelajaran. Dalam berbagai penelitian tersebut ditemukan adanya peningkatan pengetahuan dan dan keterampilan peserta didik.

Namun pada kenyataan akibat pandemi ini proses pembelajaran menjadi tidak efesien karna tidak dapat bertatap muka secra langsung, peserta didik diminta belajar dirumah menggunakan daring. Sehingga dalam proses pembelajaran peserta didik banyak yang mengeluh karna tertinggal materi pembelajaran, dan tidak dapat mengerjakan soal yang diberikan guru. Karena siswa kesulitan dalam mengerjakan soal yang diberikan guru dengan media sosial. Maka perlu diadakanya evaluasi pembelajaran daring ini yang pertama tentang implementasi pelaksanaan pembelajaran daring, yang kedua mengkaji dampak dari kebijakan pembelajaran daring, evaluasi pembelajaran daring belum dilakukan secara komperhensif.

Pelaksanaan evaluasi ini menurut (Tanjung, 2020) merupakan bagian yang harus ada dalam pelaksanaan kegiatan pembelajaran dalam memastikan tujuan sesuai standar. Dengan adanya evaluasi, diharapkan dapat diketahui pelaksanaan pembelajaran secara daring. Penilaian merupakan sistem penguji dalam pembelajaran daring untuk mengetahui seberapa jauh peserta didik yang telah dipilih dan ditetapakan oleh pendidik dalam pembelajaran. Dengan penilaian maka akan diperoleh informasi yang akurat tentang penerapan pembelajaran daring yang diukur dan dilaporkan pencapaian kompetensi tertentu, sehingga penelitian ini diharapkan dapat memberikan jawaban terkait hasil dari pembelajaran daring selama pandemi covid-19. Mengingat setiap Sekolah harus menjalanan proses pembelajaran dengan pendekatan daring ini. Permasalahan ini perlu dilakukan penelitian lebih lanjut supaya dapat diketemukan data yang valid dan sekaligus 
dapat ditentukan alternatif pemecahannya. Atas dasar tersebut maka penulis mengangkat judul "Evaluasi Implementasi Pembelajaran Daring Selama Pandemi Covid-19”.

\section{METODE PENELITIAN}

Sesuai dengan karakteristik masalah yang diangkat dalam penelitian ini maka penulis menggunakan Metode Riset kualitatif, yaitu menekankan analisanya pada data deskriptif berupa kata-kata tertulis yang diamati. Pendekatan kualitatif penulis gunakan untuk menganalisis evaluasi implementasi pembelajaran daring selama pandemi covid-19, maka dengan sendirinya penganalisaan data ini lebih difokuskan pada Penelitian Kepustakaan (Library Research), yakni dengan membaca, menelaah dan mengkaji buku-buku dan sumber tulisan yang erat kaitannya dengan masalah yang dibahas. Metode yang digunakan dalam kajian ini menggunakan metode atau pendekatan kepustakaan (library research), menurut Zed dalam (Arifudin, 2021) bahwa studi pustaka atau kepustakaan dapat diartikan sebagai serangkaian kegiatan yang berkenaan dengan metode pengumpulan data pustaka, membaca dan mencatat serta mengolah bahan penelitian, Jenis penelitian ini adalah penelitian kualitatif. Menurut Ibnu dalam (Arifudin, 2018) penelitian kualitatif adalah suatu penelitian yang datanya dinyatakan dalam bentuk verbal dan dianalisis tanpa menggunakan teknik statistik. Berdasarkan beberapa definisi penelitian kualitatif di atas, dapat disimpulkan bahwa penelitian kualitatif adalah suatu penelitian yang datanya dinyatakan dalam bentuk verbal, tidakmenggunakan angka dan analisisnya tanpa menggunakan teknik statistik.

1. Objek Penelitian

Dalam penelitian ini objek penelitian, yaitu objek formal dan objek material. Objek formal dalam penelitian ini berupa data yaitu data yang berhubungan dengan evaluasi implementasi pembelajaran. Sedangkan objek materialnya berupa sumber data, dalam hal ini adalah evaluasi implementasi pembelajaran daring selama pandemi covid-19.

2. Waktu Penelitian

Penelitian ini dilaksanakan pada bulan Agustus sampai dengan Oktober tahun 2021.

3. Teknik Pengumpulan Data

Pengumpulan data yang dilakukan dengan menggunakan teknik dokumentasi yaitu mengadakan survey bahan kepustakaan untuk mengumpulkan bahan-bahan, dan studi literatur yakni mempelajari bahan-bahan yang berkaitan dengan objek penelitian. Teknik pengumpulan data menurut (Bahri, 2021) mengemukakan bahwa merupakan langkah yang paling strategis dalam penelitian karena tujuan untama dari penelitian adalah mendapatkan data. Terdapat beberapa cara atau teknik dalam mengumpulkan data, diantaranya adalah observasi dan dokumentasi.

Sumber data yang digunakan dalam penelitian ini mencakup data primer dan sekunder. Menurut (Tanjung, 2021) bahwa data primer adalah data yang dikumpulkan langsung dari individu-individu yang diselidiki atau data tangan pertama. Sedangkan data sekunder adalah data yang ada dalam pustaka-pustaka. Data primer dalam penelitian ini adalah jurnal-jurnal terkait evaluasi implementasi pembelajaran daring selama pandemi covid-19, dan data sekunder didapatkan dari buku-buku.

4. Alat Pengumpulan Data

Dalam penelitian ini, penulis akan menggunakan metode dokumentasi sebagai alat untuk pengumpul data karena penelitian ini adalah penelitian kepustakaan. Dengan kata lain, menurut (Hanafiah, 2021) bahwa teknik ini digunakan untuk menghimpun datadata dari sumber primer maupun sekunder.

5. Teknik Analisis Data

Analisis data tidak saja dilakukan setelah data terkumpul, tetapi sejak tahap pengumpulan data proses analisis telah dilakukan. Penulis menggunakan strategi analisis "kualitatif", strategi ini dimaksudkan bahwa analisis bertolak dari data-data dan bermuara pada kesimpulan-kesimpulan umum. Berdasarkan pada strategi analisis data ini, dalam rangka membentuk kesimpulan-kesimpulan umum analisis dapat dilakukan menggunakan kerangka pikir "induktif". Menurut (Sugiyono, 2015) bahwa metode pembahasan menggunakan metode deskriptif-analisis, yaitu menjelaskan serta mengelaborasi ide-ide utama yang berkenaan dengan topik yang dibahas. Kemudian menyajikannya secara kritis melalui sumber-sumber pustaka primer maupun skunder yang berkaitan dengan tema.

6. Prosedur Penelitian

Data pada penelitian ini dicatat, dipilih dan kemudian diklasifikasikan sesuai dengan kategori yang ada. Pendekatan yang digunakan adalah pendekatan deskriptif analitis. Menurut (Rahayu, 2020) bahwa deskriptif analitis (descriptive of analyze research), yaitu 
pencarian berupa fakta, hasil dari ide pemikiran seseorang melalui cara mencari, menganalisis, membuat interpretasi serta melakukan generalisasi terhadap hasil penelitian yang dilakukan. Prosedur penelitian ini adalah untuk menghasilkan data deskriptif yang berupa data tertulis setelah melakukan analisis pemikiran (content analyze) dari suatu teks. Setelah penulis mengumpulkan bahan-bahan yang berhubungan dengan masalah yang akan di bahas dalam penelitian ini, kemudian penulis menganalisis dan menarasikan untuk diambil kesimpulan.

\section{HASIL DAN PEMBAHASAN}

Hasil dari penelitian ini diperoleh dengan cara menelaah jurnal-jurnal atau referensi yang terkait yang sudah dipilih oleh penulis, yang akan dikaji dengan metode studi literatur, yang pada akhirnya dari temuan-temuan dari masingmasing referensi akan dikerucutkan menjadi suatu hasil temuan, yang semoga dapat dijadikan acuan, referensi, saran atau masukan yang bermanfaat demi memperbaiki bidang terkait implementasi pelaksanaan pembelajaran daring dan dampak dari kebijakan pembelajaran daring.

\section{A. Implementasi pelaksanaan pembelajaran daring}

Implementasi pembelajaran bukan hanya menyasar ketersediaan, ketidaksediaan aplikasi canggih untuk pembelajaran daring, melainkan perencanaan, implementasi dan kendala-kendala guru dan peserta didik harus menjadi bagian evaluasi secara keseluruhan. Dalam pembelajaran daring, pembelajaran dimulai dari tahap persiapan, pelaksanaan dan evaluasi. Menurut (Perraton, 2002), pembelajaran daring mencakup tahap persiapan seperti kesiapan password, pelaksanaan (keaktifan peserta, ketersediaan teknologi, penguasaan teknologi), assesment pembelajaran seperti penilaian berupa kuis.

Terdapat banyak opsi aplikasi dalam menjalankan kegiatan pembelajaran daring yang bisa digunakan guru. Diantaranya adalah Ruang Guru, Zenius, Rumah Belajar, Google Classroom, Google Meet, Zoom, sampai whatsapp pun bisa digunakan untuk media dalam menyampaikan materi. Untuk platform atau aplikasi Whatsapp sendiri merupakan aplikasi yang paling sering digunakan orangorang untuk berkomunikasi. Selain mudah dipahami Whatsapp juga cenderung sedikit menghabiskan kuota internet pengguna.
Dalam pembelajaran dapat mengkombinasikan dua aplikasi sekaligus, pada saat guru menyampaikan materi dengan tatap muka secara online guru dapat menggunakan platform seperti Google Meet atau Zoom dalam menyampikan materi secara lisan. Guru dan murid pun juga dapat berinteraksi secara lisan pada platform tersebut.

Keberhasilan pembelajaran daring didukung oleh kesiapan sumber daya (guru, dan fasilitas), meningkatkan keterampilan peserta didik untuk menggunakan dan memanfaatkan teknologi, meningkatkan otonomi, kreativitas, pembelajaran mandiri peserta didik, meningkatkan pengetahuan \& keterampilan, dan proses pembelajaran yang berlanggsung dengan baik. Namun berdasarkan pendapat para guru, ada beberapa indikator yang menjadi catatan pelaksanaan pembelajaran daring yakni prinsip-prinsip pembelajaran tuntas tidak maksimal terjadi, interaksi yang terjadi antara guru dan peserta didik kurang maksimal (berbeda dengan pembelajaran konvensional), peningkatan nilai-nilai karakter kurang maksimal, motivasi, dan akurasi evaluasi terhadap kemampuan peserta didik untuk memahami materi kurang maksimal. Implementasi pembelajaran daring mendapatkan dukungan guru dengan beberapa catatan yang menjadi evaluasi bersama pengambil kebijakan di bidang pendidikan.

Peran guru dan orang tua murid menjadi sangat krusial disini, guna mengarahkan anak usia Sekolah Dasar untuk menggunakan gadget sebagai media belajar. Disaat mereka menggunakan gadget untuk media permainan saja. Guru diharapkan melakukan pendekatan dengan murid dan wali murid untuk memastikan interaksi pada saat jam pelajaran dapat dilaksanakan secara maksimal. Hal itu diperkuat dengan pernyataan (Juhji, 2020) bahwa seorang guru perlu untuk melakukan upaya pendekatan guna menggerakkan peserta didik untuk berperan aktif pada saat pembelajaran serta untuk membantu memaksimalkan minat dan bakat dari diri peserta didik.

Hal tersebut pun selaras dengan pernyataan (Mulyadi, 2009) yang menyatakan bahwa guru harus bisa mendiagnosis dan juga memiliki pemahaman terhadap tindakan yang bertujuan untuk memperbaiki keadaan kelas. Selain itu metode pembelajaran dari guru yang kurang bervariasi dapat membuat siswa 
mudah merasa bosan pada saat pembelajaran, serta kepemimpinan guru yang otoriter cenderung kurang disukai oleh siswa, karena kepemimpinan otoriter cenderung mengambil kepusutusan secara sepihak tanpa menerima pertimbangan dari pihak manapun. Selain itu peserta didik atau siswa juga berperan dalam kegiatan pembelajaran. Kurang sadarnya peserti didik dalam hal pemenuhan kewajiban belajar seperti pengerjaan tugas juga dapat menjadi faktor penghambat.

Pada saat pembelajaran jarak jauh pihak sekolah harus lebih berinteraksi dengan para wali murid. Hal itu dirasa penting untuk dilakukan mengingat pada saat pembelajaran jarak jauh seperti saat ini orang tualah yang menjadi garis terdepan bersama guru dalam memastikan materi yang disampaikan oleh pengajar dapat diserap oleh peserta didik secara maksimal. Dengan demikian bahwa orang tua peserta didik atau wali murid sangat berperan penting dalam menyukseskan jalannya pelaksanaan pendidikan dalam hal pembelajaran jarak jauh pada saat pandemi Covid-19 seperti saat ini, yaitu guna memberikan suntikan motivasi atau semangat dalam melaksanakan pembelajaran via online di rumah.

Yang dimaksud dengan peran orang tua sebagai guru adalah orang tua yang berperan layaknya seorang guru pada saat pembelajaran di kelas. Disini orang tua memiliki tugas dalam menjelaskan atau menyampaikan ulang materi pembelajara yang telah disampaikan sebelumnya oleh guru pada saat pembelajaran via online. Selain itu orang tua berperan sebagai fasilitator, dimana orang tua lah yang bertugas untuk memberikan fasilitas yang mendukung jalannya pembelajaran online tersebut, Lalu peran orang tua sebagai motivator, dalam hal ini orang harus berupaya untuk meningkatkan motivasi atau semangat belajar anak, yang kita tahu bahwa anak usia sekolah dasar lebih mempriotaskan bermain untuk mengsi waktu mereka setiap harinya, pemberian reward bagi anak yang telah menyelesaikan tugas pembelajaran dengan baik dirasa dapat membantu orang tua dalam meningkatkan motivasi atau semangat belajar pada anak. Selanjutnya peran orang tua sebagai director, dimana orang tua berupaya untuk mengarahkan kegiatan pembelajaran anak agar dapat mengikuti kegiatannya pembelajaran seperti seharusnya..
Dalam setiap kegiatan pasti terdapat kendala, maka dari itu diperlukan penyesuaian dan rasa saling memahami anatar komponen. Dalam kasus ini kendala pembelajaran daring antara lain: 1) Kurangnya literasi digital pada guru, siswa, maupun wali murid dapat menjadi kendala, 2) Masalah finansial dan geografis yang bisa menghambat kegiatan pembelajaran. Masalah finansial setap keluarga yang berbedabeda tentu saja sangat berpengaruh pada pembelajaran daring, dimana pembelajaran tersebut membutuhkan gadget dan akses internet dalam pelaksanaannya, yang dimana hal tersebut membutuhkan pengeluaran dana untuk mendapatkannya, sedangkan masih banyak keluarga dengan pemasukkan yang minim yang kesulitan untuk menjangkaunya. Ketersediaan sinyal internet dirasa masih sangat kurang bagi beberapa daerah, 3) Rasa bosan pada anak peserta didik pada saat pembelajaran. Anak pada usia masa kanakkanak akan merasa bosan apabila pembelajaran daring bersifat monoton, 4) Monotonnya metode pengajaran dari guru, serta 5) Kurangnya pengawasan orang tua.

Dalam setiap kendala pasti ada solusi. Untuk masalah finansial Kemendikbud sendiri telah menyalurkan kuota belajar dengan jumlah kuota yang menyesuaikan jenjang pendidikan. Kementrian Pendidikan dan Kebudayaan sendiri sudah mencanangkan kebijakan tentang pembelajaran jarak jauh dari rumah yang digunakan untuk tetap menjaga terselenggara kegiatan belajar yang kemudian dibentuklah program acara di televisi yang ditayangkan di TVRI mulai pukul 08.00 WIB mulai tanggal 13 April 2020 lalu.

Hal tersebut tentu saja memudahkan peserta didik yang memiliki keterbatasan dalam finansial maupun geografis untuk tetap menyerap materi pembelajaran dengan baik. Selain itu Kementrian Pendidikan dan Kebudayaan juga memberikan bantuan berupa pemberian kuota belajar yang disesuaikan dengan jenjan pendidikan di Indonesia. Pemerintah diharuskan konsisten dalam memberikan bantuan berupa fasilitas terhadap guru dan peserta didik, yang dapat dimanfaatkan untuk meningkatkan efektifitas pembelajaran.

Untuk pemilihan platform yang akan digunakan untuk pembelajaran secara daring alangkah baiknya apabila menyesuaikan kemampuan literasi digital semua komponen 
yang terlibat, seperti guru, peserta didik dan wali murid. Sehingga semua pihak terkait dapat mengoperasikan platform dengan mudah yang nantinya dapat menunjang pelaksanaan pembelajaran itu sendiri. Kemudian untuk mengatasi rasa bosan pada siswa akibat metode pembelajaran yang monoton guru dapat melakukan variasi pada saat mengajar. Pembelajaran daring akan mempermudah variasi pembelajaran berupa audio dan video yang dapat dikreasikan guru sebaik mungkin. Bisa saja dengan mengganti background aplikasi pada saat live Zoom, Google Meet atau aplikasi lainnya. Guru juga bisa meminta siswa untuk memakai seragam agar menambah nuansa pembelajaran seperti pada saat pembelajaran tatap muka langsung dikelas. Lalu yang terakhir berupa kerja sama saling mengingatkan antara guru dan wali murid pada saat sebelum dan sesudah pembelajaran berlangsung guna melakukan evaluasi bersama terkait pembelajaran, agar peserta didik dapat memaksimalkan sumber daya yang terkait pembelajaran dengan baik pembelajaran dengan baik.

Penelitian dari (Toquero, 2020) yang dimana penelitian tersebut membahas tentang tantangan dan hambatan sekaligus peluang yang terjadi di dunia pendidikan pada saat menghadapi pandemi covid-19 khususnya di Negara Filipina. Tantangan yang disebutkan antara lain membenahi sistem pendidikan secara massif baik dari segi perencanaan, pelaksanaan, maupun aspek penilaian. Akan tetapi menurut penelitian tersebut dijelaskan pula bahwa terdapat peluang juga yaitu untuk meningkatkan metode penyampaian dalam pembelajaran dan juga berpeluang meningkatkan atau mengembangkan lagi sistem layanan berbasis digital. Penelitian berikutnya membahas tentang perbandingan antara pembelajaran tatap muka dengan pembelajaran online. Menurut (Ni, 2013) pembelajaran online sendiri dapat mengurangi presensi kehadiran dari para peserta didik, akan tetapi di sisi lain juga dapat meningkatkan efektivitas pembelajaran bagi siswa yang cenderung pendiam pada saat pembelajaran tatap muka secara langsung. Karena siswa tersebut akan merasakan atmosfer yang berbeda pada saat pembelajaran online, hal tersebut dinilai dapat mengurangi tingkat kegugupan peserta didik. Penelitian ini juga memuat tentang metode pembelajaran yang harus dikembangkan lagi tentang bagaimana mengatur kelas campuran agar dapat meningktkan efektivitas ruang dan waktu dalam pembelajaran.

\section{B. Dampak dari kebijakan pembelajaran daring.}

Implementasi pembelajaran daring merupakan salah satu upaya untuk mengukur sejauh mana keberhasilan pelaksanaan pembelajaran daring di sekolah dasar khususnya selama pandemik COVID-19. Dari hasil penelitian ditemukan bahwa tidak semua indikator pelaksanaan pembelajaran daring berhasil, ada beberapa indikator tertentu yang menjadi catatan khusus untuk diperbaiki di masa depan. Hal ini sejalan penelitian sebelumnya yang mengatakan bahwa pembelajaran berbasis daring belum dimanfaatkan secara optimal dan sering terjadinya gangguan jaringan internet. Masalah-masalah bersifat teknis dapat terjadi juga karena jarak atau kecepatan jaringan internet sehingga materi pembelajaran kurang maksimal. Kendala yang dialami dalam implementasi sistem pembelajaran daring dapat terjadi seperti keaktifan peserta didik dalam mengikuti aktivitas pembelajaran cenderung menurun dengan berjalannya waktu dan belum adanya kesadaran peserta didik dalam menjalankan etika menggunakan internet. Dari berbagai referensi yang ada setelah dievaluasi pembelajaran daring, bahwa mengajar dengan teknologi bukan satusatunya ukuran yang cocok untuk semua pendekatan pembelajaran. Semua tergantung pada konten kurikulum yang digunakan. Menurut Xie dalam (Arifudin, 2019) bahwa Teknologi memberikan faktor tambahan untuk dipertimbangkan dalam hal pengajaran pedagogi dan konstruksi pengalaman belajar, Tantangan lain dalam pembelajaran daring adalah kerja kelompok, keterlibatan, akses, komunitas, dan dukungan.

Kebijakan pembelajaran jarak jauh telah memberikan peluang penggunaan aplikasi teknologi untuk kegiatan pembelajaran. Keberhasilan implementasinya didukung oleh sumber daya (guru dan fasilitas) yang baik. Kesiapan sumber daya guru dan fasilitas mendapatkan nilai tertinggi $(4,13)$. Hal ini terjadi karena guru telah terlatih memanfaatkan teknologi dalam pembelajaran konvensional/tata muka sehingga mereka telah siap mengimplementasikan kebiasaan tersebut selama pandemik COVID-19. Penguasaan 
teknologi oleh peserta didik mendapatkan nilai baik $(3,83)$. Dalam perspektif pendidik, peserta didik memiliki keterampilan untuk menggunakan dan memanfaatkan aplikasi teknologi untuk kegiatan pembelajaran jarak jauh. Selama pandemik COVID-19, pengetahuan dan keterampilan peserta didik memanfaatkan aplikasi teknologi dapat ditingkatkan. Peserta didik mampu beradaptasi dengan cepat pada penggunaan aplikasi teknologi canggih.

Indikator keberhasilan pengelolaan kelas sendiri menurut (Arikunto, 2004) antara lain: 1) Terciptanya lingkungan belajar yang kondusif, tertib, disiplin dan bergairah; 2) adanya hubungan yang baik antara siswa dan guru maupun guru dan siswa secara interpersonal, anak usia Sekolah Dasar merupakan usia dimana anak-anak mulai belajar beradaptasi dengan lingkungan, untuk anak Sekolah Dasar kelas 4-6 biasanya merupakan tahapan anak mulai beranjak remaja. Pada usia tersebut mayoritas dari mereka akan menghabiskan waktunya untuk bermain dan bersenangsenang. Oleh karena terdapat perbedaan kondisi psikologis yang berbeda, maka diperlukan pendekatan tertentu dalam pembelajaran agar hasil yang diperoleh dapat maksimal. Hal ini sesuai dengan implikasi teori perkembangan oleh piagiet, antara lain 1) Bahasa dan cara berfikir anak berbeda dengan orang dewasa, maka dari itu guru sebaiknya menggunakan cara penyampaian yang sesuai dengan persepsi berfikir anak; 2) Anak-anak akan belajar lebih baik jika dapat beradaptasi dengan lingkungan dengan baik, salah satu tugas guru adalah dengan membantu proses adaptasi siswa di sekolah dengan menciptakan lingkungan yang aman dan kondusif (UPI, 2007).

Lingkungan sekolah yang baik akan membantu dalam pelaksanaan kegiatan belajar mengajar. Lingkungan sekolah yang kondusif merupakan salah satu aspek tercapainya pendidikan yang efektif. Hal itupun selaras dengan pernyataan (Mulyasa, 2002) tentang penciptaan iklim sekolah yang mengemukakan bahwa iklim sekolah yang kondusif serta memiliki sifat positif seperti optimis dan mempunyai harapan yang tinggi dari warga sekolah serta menciptakan kegiatan yang terpusat pada siswa merupakan iklim lingkungan sekolah yang ideal untuk menumbuhkan semangat belajar, memaks- imalkan potensi siswa dan dapat membantu menumbuhkan karakter pada siswa. Untuk menciptakan iklim atau lingkungan yang positif tersebut diperlukan kerja sama dari elemen-elemen yang terkait. Seperti yang dijelaskan (Wibowo., 2013) bahwa perlu adanya kerja sama antara elemen terkait, seperti murid, guru, wali murid, kepala sekolah serta sarana dan prasaran yang memadai. Hal tersebut perlu diaplikasikan guna menunjang kefektifan pembelajaran.

\section{SIMPULAN DAN SARAN}

\section{A. Simpulan}

Dari hasil pembahasan pada penelitian ini, maka dapat disimpulkan beberapa hal yakni :

1. Hasil analisis data menunjukkan bahwa pembelajaran daring di Sekolah Dasar selama pandemik COVID-19 mampu meningkatkan pengetahuan, keterampilan, penguasaan teknologi, otonomi, kreativitas, kemandirian peserta didik dan menunjukkan kesiapan institusi sekolah baik guru maupun fasilitas untuk melaksanakan pembelajaran jarak jauh.

2. Hasil analisis data menunjukkan bahwa pembelajaran daring kurang maksimal pada peningkatan kemampuan peserta didik khususnya yang bersifat non akademis seperti pembentuk karakter, efektivitas interaksi dalam pembelajaran, pembelajaran tuntas, peningkatan kepribadian, pemberian motivasi yang berorientasi pada keteladanan hidup dan akurasi evaluasi terhadap peningkatan kemampuan peserta didik.

\section{B. Saran}

Penelitian ini merupakan kajian awal tentang evaluasi implementasi pembelajaran daring selama pandemi covid-19 terkait implementasi pelaksanaan pembelajaran daring dan dampak dari kebijakan pembelajaran daring, sehingga diperlukan adanya tindak lanjut yang lebih mendalam dalam membahas implementasi pelaksanaan pembelajaran daring dan dampak dari kebijakan pembelajaran daring. Pada penelitian berikutnya bisa melakukan penelitian secara komprehensif terkait implementasi pelaksanaan pembelajaran daring dan dampak dari kebijakan pembelajaran daring.

\section{DAFTAR RUJUKAN}

Allo. (2020). In the Online Learning Good in the Midst of Covid-19 Pandemic? The Case of EFL Learners. Jurnal Sinestesia, 10(1), 1-10. 
Arifudin, 0. (2018). Pengaruh Pelatihan Dan Motivasi Terhadap Produktivitas Kerja Tenaga Kependidikan STIT Rakeyan Santang Karawang. MEA (Manajemen, Ekonomi, \& Akuntansi), 2(3), 209-218.

Arifudin, O. (2019). Manajemen Sistem Penjaminan Mutu Internal (Spmi) Sebagai Upaya Meningkatkan Mutu Perguruan Tinggi. MEA (Manajemen, Ekonomi, \& Akuntansi), 3(1), 161-169.

Arifudin, O. (2020). Manajemen Perguruan Tinggi Era Revolusi 4.0 Dalam Meningkatkan Daya Saing Perguruan Tinggi Nasional. Jurnal AlAmar (Ekonomi Syariah, Perbankan Syariah, Agama Islam, Manajemen Dan Pendidikan), 2(1), 1-8.

Arifudin, 0. (2021). Implementasi Balanced Scorecard dalam Mewujudkan Pendidikan Tinggi World Class. Edumaspul: Jurnal Pendidikan, 5(2), 767-775.

Arikunto, S. (2004). Dasar-Dasar Supervisi. Jakarta: PT Reneka Cipta.

Arina. (2018). Education as Human Capital Aspect. International Multidiciplinary Scientific Conference on Social Science \& Arts.

Bahri, A. S. (2021). Pengantar Penelitian Pendidikan (Sebuah Tinjauan Teori dan Praktis). Bandung: Widina Bhakti Persada.

Hanafiah. (2021). Pelatihan Software Mendeley Dalam Peningkatan Kualitas Artikel Ilmiah Bagi Mahasiswa. Jurnal Karya Abdi Masyarakat, 5(2), 213-220.

Handayani. (2020). Penyakit Virus Corona 2019. Jurnal Respirologi Indonesia., 40(2), 120129.

Hasbi, I. (2021). Administrasi Pendidikan (Tinjauan Teori Dan Praktik). Bandung: Widina Bhakti Persada.

Irwansyah, R. (2021). Perkembangan Peserta Didik. Bandung : Widina Bhakti Persada.

Juhji. (2020). Manajemen Humas Sekolah. Bandung: Widina Bhakti Persada.

Karim. (2004). The Experience of e-learning Implementation at the Universiti Pendidikan Sultan Idris, Malaysia. Malasian
Online Journal of Instructional Technology., 1(1), 50-59.

Maltz. (2005). Top Ten IT Issues. Educause Review, 40(1), 15-28.

Mayasari, A. (2021). Implementasi Sistem Informasi Manajemen Akademik Berbasis Teknologi Informasi dalam Meningkatkan Mutu Pelayanan Pembelajaran di SMK. JIIPJurnal Ilmiah Ilmu Pendidikan, 4(5), 340345. https://doi.org/10.54371/jiip.v4i5.277

Mulyadi. (2009). Classroom Manajement Mewujudkan Suasana Kelas Yang Menyenangkan Bagin Siswa. Malang: Aditya Media.

Mulyasa. (2002). Manajemen Berbasis Sekolah, Konsep, Strategi, dan Implementasi. Bandung: PT. Remaja Rosdakarya.

Nadeak, B. (2020). Manajemen Humas Pada Lembaga Pendidikan. Bandung: Widina Bhakti Persada.

Nasser, A. A. (2021). Sistem Penerimaan Siswa Baru Berbasis Web Dalam Meningkatkan Mutu Siswa Di Era Pandemi. Biormatika: Jurnal Ilmiah Fakultas Keguruan Dan Ilmu Pendidikan, 7(1), 100-109.

Ni. (2013). Comparing the Effectiveness of Classroom and Online Learning: Teaching Research Methods. JPAE: Journal of Public Affairs Education, 19(2), 199-215.

Perraton. (2002). Open and Distance Learning in the Developing World. London: Routledge.

Rahayu, Y. N. (2020). Program Linier (Teori Dan Aplikasi). Bandung : Widina Bhakti Persada.

Sugiyono. (2015). Metode Penelitian Pendidikan (Pendekatan Kuantitatif,. Kualitatif dan $R \& D)$. Bandung : CV. Alfabeta.

Tanjung, R. (2019). Manajemen Pelayanan Prima Dalam Meningkatkan Kepuasan Mahasiswa Terhadap Layanan Pembelajaran (Studi Kasus di STIT Rakeyan Santang Karawang). MEA (Manajemen, Ekonomi, \& Akuntansi), 3(1), 234-242.

Tanjung, R. (2020). Pengaruh Penilaian Diri Dan Efikasi Diri Terhadap Kepuasan Kerja Serta Implikasinya Terhadap Kinerja Guru. Jurnal 
Ilmiah MEA (Manajemen, Ekonomi, Dan Akuntansi), 4(1), 380-391.

Tanjung, R. (2021). Kompetensi Manajerial Kepala Sekolah Dalam Meningkatkan Kinerja Guru Sekolah Dasar. JIIP-Jurnal Ilmiah Ilmu Pendidikan, 4(4), 291-296. https://doi.org/10.54371/jiip.v4i4.272

Toquero. (2020). Challenges and Opportunities for Higher Education amid the COVID-19 Pandemic: The Philippine Context. Pedagogical Research., 5(4), 1-8.

UPI. (2007). Ilmu dan Aplikasi Pendidikan. Bandung: Pedagogiana Press.
Wentling. (2000). E-learning - a review of literature. Knowledge and Learning Systems Group NCSA, 9(3), 1-7.

Wibowo. (2013). Manajemen Perubahan. Jakarta: Raja Grafindo Persada.

Wicaksono. (2017). Pembelajaran Blended Learning Melalui Google Classroom Di Sekolah Dasar. Seminar Nasional Pendidikan PGSD UMS \& HDPGSDI Wilayah Jawa.

Yaniawati. (2013). E-Learning to Improve Higher Order Thinking Skills (HOTS) of Students. Journal of Education and Learning, 7(2), 109-120. 